\title{
KEBIJAKAN REKLAMASI DAN REVEGETASI LAHAN BEKAS TAMBANG (STUDI KASUS TAMBANG BATUBARA INDONESIA)
}

\author{
Sarita Oktorina \\ UIN Sunan Ampel, Surabaya \\ sarita@uinsby.ac.id
}

\begin{abstract}
Abstrak
Reklamasi adalah kegiatan pengelolaan tanah yang mencakup perbaikan kondisi fisik tanah (overburden) agar tidak terjadi longsor, pembuatan waduk untuk perbaikan kualitas air asam tambang yang beracun, yang kemudian dilanjutkan dengan kegiatan revegetasi. Kegiatan reklamasi penting dilakukan untuk memperbaiki lahan bekas tambang. Pada umumnya tanah di lahan bekas tambang mengandung kadar unsur hara yang rendah. Reklamasi dan revegetasi merupakan kegiatan yang dilakukan untuk memperbaiki kondisilahan pasca penambangan. (Pujawati, 2009). Dalam melaksanakan reklamasi, pemerintah mengeluarkan berbagai kebijakan guna memastikan bahwa setiap perusahaan wajib melaksanakan reklamasi dengan benar, baik dan sungguh-sungguh, serta menyetorkan dana jaminan reklamasi. Untuk merealisasikannya, perlu dilakukan adanya perizinan, yaitu setiap perusahaan yang melakukan kegiatan pertambangan harus segera merencanakan bentuk kegiatan pasca tambang (reklamasi) di atas areal tambang yang digunakan paling lambat satu bulan setelah tidak ada lagi kegiatan usaha pertambangan pada lahan yang terganggu. Selain itu, perlu juga dilakukan pengendalian lahan pasca tambang dengan memadukan pembenahan lahan, dan pemilihan jenis tanaman yang tepat, yaitu dengan kriteria berjenis local pioner cepat tumbuh, tahan terpapar matahari, cepat terdekomposisi, sistem perakaran yang baik dan bersimbiosis dengan mikroorganisme tertentu, mudah dan murah dalam perbanyakan, penanaman dan pemeliharaan.

Kata Kunci: reklamasi, lahan, kebijakan, perizinan
\end{abstract}

\section{PENDAHULUAN}

Sektor pertambangan merupakan salah satu penggerak roda perekonomian dan pembangunan nasional yang terbesar bagi Indonesia termasuk batubara. Total sumber daya batubara di Indonesia tahun 2011 diperkirakan mencapai 105 miliar ton. Saat ini, 75\% dari total produksi batubara diekspor, terutama ke Jepang, Taiwan, Korea Selatan dan Eropa, dan sisanya untuk kebutuhan dalam negeri (ESDM, 2011).

Tambang batubara di Indonesia umumnya dilakukan dengan sistem tambang terbuka (open pit mining) sehingga berdampak terhadap kerusakan lingkungan. Dampak kerusakan lingkungan antara lain hilangnya vegetasi hutan, flora dan fauna serta lapisan tanah. Oleh karena itu setiap perusahaan yang melakukan kegiatan pertambangan wajib melaksanakan reklamasi lahan bekas pertambangannya (Patiung, dkk., 2011).
Terkait dengan hal di atas, maka sepatutnyalah bagi pemerintah untuk mengambil berbagai kebijakan tentang reklamsi. Dalam hal ini bukan haya pemerintah pusat namun juga pemerintah daerah, perusahaan dan bantuan masyarakat. Seperti yang tertuang dalam Undang-Undang No. 32 Tahun 2004 tentang Pemerintah Daerah, Pasal 22 yang menyatakan bahwa salah satu kewajiban otonomi daerah adalah (b) meningkatkan kualitas kehidupan masyarakat dan butir (k) melestarikan lingkungan hidup.

Oleh karena itu, perlu dilakukan analisa lebih lanjut mengenai kebijakan reklamasi dan revegetasi lahan bekas tambang sebagai bentuk pengendalian lahan pasca penambangan batubara.

Reklamasi adalah suatu kegiatan pengelolaan tanah yang mencakup perbaikan kondisi fisik tanah (overburden) agar tidak terjadi longsor, pembuatan 
waduk untuk perbaikan kualitas air asam tambang yang beracun, yang kemudian harus dilajutkan dengan melakukan revegetasi. Pada dasarnya reklamasi dan revegetasi merupakan salah satu usaha yang dilakukan untuk memperbaiki kondisi lahan pasca penambangan. (Pujawati, 2009).

Salah satu bentuk reklamasi adalah dengan melakukan alih fungso lahan bekas tambang menjadi lahan pertanian tanaman pangan dengan melakukan tiga tahapan reklamasi. Pemulihan fungsi lahan, peningkatan fungsi lahan, dan pemeliharaan fungsi lahan. (Hermawan, 2011).

Prinsip kegiatan reklamasi adalah :

1. Reklamasi harus dianggap sebagai kesatuan yang utuh dari kegiatan penambangan.

2. Kegiatan reklamasi harus dilakukan sedini mungkin serta tidak harus menunggu proses penambangan secara keseluruhan selesai dilakukan.

Pelaksanaan reklamasi wajib dilakukan pada lahan yang terganggu akibat pertambangan baik di daerah ekas tambang maupun daerah luar bekas tambang. Lahan di luar bekas tambang meliputi : timbunan tanah penutup, timbunan bahan baku, jalan transportasi, pabrik/instalasi pengolahan/pemurnian, kantor dan perumahan, serta pelabuhan/dermaga.

\section{METODE PENELITIAN}

Metode yang digunakan adalah studi literature dengan menggunakan data sekunder dengan melakukan studi pustaka. Analisis yang digunakan adalah analisis kualitatif yaitu dalam bentuk deskriptif dengan menyajikan gambaran data melalui studi pustaka tersebut, serta menguraikan dan menginterpretasikan data tersebut.

\section{HASIL DAN PEMBAHASAN}

Terkait dengan pelaksanaan reklamasi sebagaimana disebutkan dalam Undang-undang Nomor 4 Tahun 2009 tentang Mineral dan batubara dimana setiap perusahaan pengelola tambang wajib melakukan reklamasi. Kemudian untuk memastikan bahwa tanggung jawab perusahaan pengelola tambang melaksanakan reklamasi dengan baik dan sungguh-sungguh, maka setiap perusahaan diwajibkan menyetor dana jaminan reklamasi dalam bentuk deposito ke Bank Pemerintah yang ditunjuk. Hal ini sebagaimana diatur dalam peraturan pemerintah nomor 78 Tahun 2010 tentang reklamasi dan pasca tambang pasal 29 ayat (1) yang menjelaskan bahwa pemegang IUP dan IUPK wajib menyediakan jaminan reklamasi dan jaminan pascatambang. Kemudian pada ayat (2) menjelaskan bahwa jaminan reklamasi sebagaimana dimaksud pada ayat (1) terdiri dari jaminan reklamasi tahap eksplorasi dan jaminan reklamasi tahap operasi produksi.

Oleh karena itu, perusahaan tambang batubara harus segara merencanakan bentuk kegiatan pasca tambang dalam rangka merelokasi ulang hal-hal yang sifatnya social kemasyarakatan. Undang-undang No. 4 Tahun 2009 tentang Pertambangan Mineral dan Batubara mewajibkan perusahaan pertambangan untuk melakukan reklamasi dan kegaiatan pascatambang atas areal tambang yang diusahakannya. Untuk memberikan efek memaksa bagi para pengusaha pertambangan guna melakukan reklamasi, para pengusaha tersebut diwajibkan untuk menyerahkan sejumlah uang sebagai jaminan reklamasi, yang harus ditempatkan sebelum perusahaan melakukan kegiatan operasi produksi.

\section{A. PERIZINAN REKLAMASI PASCA TAMBANG}

Agar kegiatan reklamasi dan pasca tambang dapat terlaksana dan memenuhi kriteria keberhasilan, maka ada beberapa tahapan yang harus dilalui, yaitu permohonan izin tata laksana rencana reklamasi dan rencana pasca tambang, persetujuan rencana reklamasi dan rencana pasca tambang, hingga perubahan rencana reklamasi dan rencana pasca tambang. Proses tahapan tersebut diatur pada Peraturan Pemerintah Nomor 78 Tahun 2010 yang terlebih dahulu harus melalui izin dari menteri, gubernur, bupati/walikota. Kemudian menyediakan dana jaminan reklamasi dan dana jaminan pasca tambang yang merupakan salah satu kewajiban yang harus dilakukan.

Pemerintah menetapkan kebijakan bagi setiap pemegang IUP dan IUPK untuk menempatkan jaminan reklamasi dan jaminan pascatambang. Jaminan diperlukan sebagai wujud kesungguhan setiap 
pemegang IUP dan IUPK untuk memulihkan lahan bekas tambang dan lahan diluar bekas tambang sesuai peruntukkan yang disepakati para pemangku kepentingan dalam rangka pembangunan berkelanjutan. Besarnya jaminan pascatambang dihitung berdasarkan biaya:

a. Biaya langsung meliputi:

1) Pembongkaran bangunan dan sarana penunjang yang sudah tidak digunakan;

2) Reklamasi tapak bekas tambang, fasilitas pengolahan dan pemurnian, serta fasilitaspenunjang;

3) Penanganan Bahan Berbahaya dan Beracun (B3) dan limbah B3;

4) Pemeliharaan dan perawatan;

5) Pemantauan;

6) Aspek sosial, ekonomi, dan budaya.

b. Biaya tidak langsung meliputi:

1) Mobilisasi dan demobilisasi;

2) Perencanaan kegiatan;

3) Administrasi dan keuntungan pihak ketiga sebagai kontraktor pelaksana penutupan tambang;

4) Supervisi.

Jaminan tersebut ditempatkan setiap tahun dalam bentuk deposito berjangka pada bank pemerintah. Deposito berjangka tersebut berlaku sampai seluruh kegiatan pascatambang dinyatakan selesai oleh gubernur. Untuk pencairan deposito berjangka beserta bunganya dilakukan setelah kegiatan pascatambang sesuai dengan tahapan penyelesaian pekerjaan yang telah dilakukan berdasarkan rencana pascatambang yang disetujui dan diterima oleh gubernur.

$\begin{array}{ccc}\text { Penempatan } & \text { jaminan pasca } \\ \text { tambang oleh perusahaan tidak }\end{array}$ menghilangkan kewajiban perusahaan untuk melaksanakan kegiatan pascatambang. Apabila perusahan kekurangan biaya perencanaan reklamasi, penempatan jaminan reklamasi, pelaksanaan reklamasi, pelepasan atau pencairan jaminan reklamasi untuk menyelesaikan kegiatan pascatambang dari jaminan yang telah ditetapkan maka tetap menjadi tanggungjawab perusahaan.

Pelaksanaan reklamasi wajib dilakukan pada lahan yang terganggu akibat pertambangan. Lahan tersebut baik berada pada bekas tambang maupun lahan di luar bekas tambang yang tidak digunakan lagi. Lahan di luar bekas tambang meliputi:

(1) Timbunan tanah penutup;

(2) Timbunan bahan baku/produksi;

(3) Jalan transportasi;

(4) Pabrik/instalasi pengolahan/pemurnian;

(5) Kantor dan perumahan; dan/atau

(6) Pelabuhan/dermaga.

Pelaksanaan reklamasi dilakukan paling lambat satu bulan setelah tidak ada lagi kegiatan usaha pertambangan pada lahan. Sedangkan laporan pelaksanaan reklamasi dilaksanakan setiap satu tahun kepada gubernur.

\section{B. REVEGETASI LAHAN BEKAS TAMBANG}

Penambangan di Indonesia umumnya dilakukan dengan cara terbuka atau open pit mining. Pengambilan biji tambang dilakukan dengan terlebih dahulu membersihkan area tambang dari vegetasi (land clearing) diikuti dengan mengupas lapisan-lapisan tanah hingga sampai pada deposit biji tambang. Lapisan tanah pucuk disisihkan di tempat khusus untuk digunakan pada saat penimbunan atau reklamasi. Setelah biji tambang terambil, lubang tambang diisi kembali dengan tanah bekas galian (overburden) dan tailing (tanah limbah sisa proses pengambilan biji tambang), dipadatkan dan kemudian ditutup dengan lapisan tanah pucuk yang sebelumnya telah disisihkan untuk kemudian ditanami. Dengan kondisi yang seperti itu maka lahan bekas tambang umumnya memiliki ciri lapisan tanah pucuk dan sub soil yang tipis sehingga sedikit pula bahan organik tanah beserta mikroba tanah yang sangat diperlukan untuk pertumbuhan tanaman.

Lahan dengan kondisi ekstrim tersebut tidak mungkin begitu saja direvegetasi. Oleh karena itu keberhasilan revegetasi lahan bekas tambang hanya dapat dicapai dengan memadukan pembenahan tanah, pemilihan jenis dan penerapan teknik silvikultur yang tepat. Pemilihan jenis pohon menjadi bagian penting dalam kegiatan revegetasi. Kesalahan dalam pemilihan jenis menghantarkan pada kegagalan revegetasi. Pada lahan bekas 
tambang batubara yang sangat terbuka dengan tanah yang marginal maka jenis yang dipilih sebaiknya memiliki kriteria sebagai berikut: jenis lokal pioner cepat tumbuh, tahan terpapar matahari (shade intolerant), menghasilkan serasah yang banyak dan cepat terdekomposisi, sistem perakaran yang baik dan bersimboisis dengan mikroorganisme tertentu, bersifat katalitik, mudah dan murah dalam perbanyakan, penanaman dan pemeliharaan.

\section{PEMELIHARAAN PASCA PENAMBANGAN}

Pemeliharaan yang dilakukan pasca penambangan adalah (Parascita, 2015) :

a. Pemeliharaan Lereng (Jenjang) Berdasarkan analisis kemantapan lereng, dimensi lereng yang digunakan menunjukan bahwa lereng akhir penambangan dalam kondisi yang stabil. Pemeliharaan lereng lebih didominasi dengan penanaman pohon di jenjang akhir penambangan sebagai bentuk upaya dari revegetasi serta mengambil atau mengeruk batuan di jenjang yang menggantung jika ada.

b. Pemeliharaan Tanaman Revegetasi Pemeliharaan tanaman revegetasi bertujuan untuk menjaga semua tanaman yang direvegetasi tumbuh baik dan sehat. Selain itu, pemeliharaan ini menjaga semua jenis tumbuhan yang ditanam agar tidak mengalami gangguan atau kerusakan baik yang disebabkan oleh kegiatan manusia ataupun sebagai akibat dari kegiatan hama dan penyakit yang dapat menyerang tanamanan.

c. Pemeliharaan Lubang Bekas Penambangan

Pemeliharaan terhadap lubang bekas penambangan bertujuan untuk mencegah banjir atau meluapnya air ke permukaan karena seluruh lubang bekas penambangan dimanfaatkan sebagai kolam resapan dan kolam karambah ikan. Upaya yang dilakukan yaitu dengan cara melakukan pemantauan terhadap jenjang, saluran air di sekeliling lubang dan tanggul penahan air.

\section{PENGARUH PEMILIHAN TANAMAN REVEGETASITERHADAP KRITERIA KEBERHASILAN REKLAMASI}

Reklamasi dinilai berhasil apabila telah memenuhi kriteria keberhasilan reklamasi yang ditetapkan. Dalam hal ini untuk kegiatan revegetasi perlu memperhatikan antara jenis tanaman yang dipilih dan syarat tumbuh tanaman dengan kondisi lahan, agar kriteria keberhasilan reklamasi dapat tercapai. Apabila pemilihan tanaman tepat dan sesuai terhadap kondisi lahan yang akan direklamasi, maka :

a. Tanaman dapat tumbuh dengan baik

b. Persentase tumbuh tanaman yang diinginkan tercapai

c. Jumlah tanaman tiap Hektar memenuhi target

d. Kombinasi jenis tanaman sesuai serta kesehatan tanaman baik.

Jika hal tersebut terlaksana maka keberhasilan reklamasi pada aspek revegetasi dapat dikatakan berhasil karena telah sesuai dengan kriteria keberhasilan reklamasi yang ditetapkan (Parascita, 2015).

\section{KESIMPULAN}

Reklamasi lahan bekas tambang sudah seharusnyalah dilakukan agar tanah tersebut dapat digunakan kembali.

\section{DAFTAR PUSTAKA}

ESDM, 2011. Sumber Daya Batubara Indonesia Capai 105 Miliar Ton. Jakarta. http://www.esdm.go.id/berita/batu bara/44-batubara/4557-

sumberdaya-batubaraindonesiacapai-105-miliar-ton.html

Hermawan, Bandi. 2011. Peningkatan Kualitas Lahan Bekas Tambang melalui Revegetasi dan Kesesuaiannya sebagai Lahan Pertanian Tanaman Pangan. Prosiding Seminar Nasional Budidaya Pertanian, Urgensi dan Strategi Pengendalian Alih Fungsi Lahan Pertanian. Bengkulu.

Maharani, R., Adi S., Sri S., dan Andrian F., 2010. Revegetasi Lahan Bekas Tambang Batubara. Status Riset Reklamsi Bekas Tambang Batubara. Samarinda.

Nurlaela, Abrar S., dan Farida P., 2014. Tanggung Jawab Hukum Reklamasi 
Lahan Bekas Pertambangan PT. Kaltim Prima Coal di Kabupaten Kutai Timur.

Parascita, L., Anton S., dan Gunawan N., 2015. Rencana Reklamasi pada Lahan Bekas Penambangan Tanah Liat di Kuari Tlogowarupt. Semen Indonesia (Persero) Tbk. Pabrik Tuban, Jawa Timur. Jurnal Teknologi Pertambangan Vol. 1 (1) Periode: Maret-Agustus 2015.

Pasal 35 Ayat (4) Peraturan Menteri Energi Dan Sumber Daya Mineral Nomor 18 Tahun 2008

Pasal 37 Peraturan Menteri Energi Dan Sumber Daya Mineral Nomor 18 Tahun 2008

Pasal 15 Peraturan Menteri Energi Dan Sumber Daya Mineral Nomor 18 Tahun 2008

Pasal 100 UU No. 4 Tahun 2009 Tentang Pertambangan Mineral dan Batubara

Patiung, O., Naik S., Suria D. T., dan Dudung D., 2011. Pengaruh Umur Reklamasi Lahan Bekas Tambang Batubara Terhadap Fungsi Hidrologis. JurnalHidrolitan, Vol 2 (2) : 60-73

Prayogo, Dody. 2008. Corporate Social Responsibility, Social Justice dan Distributive Welfare dalam Industri Tambang dan Migas di Indonesia, Jurnal Galang Vol. 3 (3) Desember 2008.

Pujawati, E. D., 2009. Jenis-jenis Fungi Tanah pada Areal Revegetasi Acacia mangium Willd di Kecamatan Cempaka Banjarbaru.Jurnal Hutan Tropis Borneo Volume 10 (28), Edisi Desember 2009

Purnamayani, R., J. Hendri, dan H. Purnama.2016. Karakteristik Kimia Tanah Lahan Reklamasi Tambang Batubara di Provinsi Jambi. Prosiding Seminar Nasional Lahan Suboptimal 2016, Palembang. 